Please note that this paper is an unformatted version of the final published paper. Please consult the published version when citing this paper.

\title{
Authors
}

Stephen Vainker and Adrian R. Bailey

Research conducted at the University of Exeter Business School, Department of Management Studies, Exeter, UK

Stephen Vainker

Independent Scholar

stephenvainker@hotmail.com

Adrian R. Bailey

The University of Exeter Business School, Streatham Court, Rennes Drive, Exeter, EX4 4PU, UK

a.r.bailey@exeter.ac.uk 


\section{Students as human resources in the corporatised school}

\section{Abstract}

The transfer of Human resource management (HRM) practices from the corporate business context into schools has taken a novel turn. No longer restricted to the management of school teachers, HRM techniques are now being applied to the management of students. HRM views the student as a human resource to serve the school, and seeks to systematically regulate students' identities in order to align them with school values and goals. The paper introduces the Uncommon Schools model as an exemplar of student centred HRM. The case study demonstrates how student-centred HRM is being operationalised in schools and concludes by exploring the potential of this systematic innovation in student management. The paper is informed by critical management theories and argues that student centred HRM constitutes a radical shift in the relationship between school and student.

Keywords: culture; HRM; identity; schools; students; teachers

\section{Introduction}

This paper examines the position of the student in corporatised schools, schools which have been reformed so that their purpose, structures and processes mimic those of the business world (Courtney 2015a). The corporatised roles of adults in schools have been 
well-documented by, amongst others, Wilkins (2015) in relation to governors, Grace (1995) and Gunter (2012) in relation to headteachers, and Ball (2003) and Courtney and Gunter (2015) in relation to teachers. The contribution of this paper is to demonstrate that the role of the student is potentially no less affected by corporatisation.

In the paper we demonstrate that the scope of the human resource management (HRM) system in schools potentially extends to incorporate students alongside teachers. HRM has been used as a term to capture the relationship between the school and the teacher (but not yet the student) under new public management (Hatcher 1994). HRM repositions the teacher from being an autonomous professional, working within the confines of bureaucratic rules, to a resource that has an instrumental value to the principal in delivering their 'vision' for the school (Courtney and Gunter 2015). As with any other resource, the school must extract maximum value from teachers, and it is the responsibility of the school leadership to ensure that that the teachers are demonstrating the requisite effort and commitment. This is achieved through a combination of 'hard' structural and 'soft' cultural approaches to management. The structural element involves measuring, monitoring and, where necessary, intervening in the work of teachers; the cultural element aims to influence the attitudes, values, and feelings of teachers so that teachers experience working towards the principal's 'vision' as personally meaningful (ibid.).

The paper provides a detailed account of a comprehensive HRM school model, codified by Doug Lemov (2015) and Paul Bambrick-Santoyo (2012), which incorporates students through an intensively-managed, top-down 'student culture'. Their work on student culture, a well-established concept endorsed by Ofsted (2016), is a particularly fully-developed, clearly-articulated example of the corporatised position of the student in the contemporary school. It is also a model that possesses significant international 
influence. From their base at the Uncommon Schools network of charter schools, the work of Lemov, 'the closest thing that teaching has to a cult celebrity' (Vaughan 2014), and Bambrick-Santoyo has gained prominence within the 'Global Education Reform Movement', a network of groups who share the goal of updating bureaucratic approaches to education by introducing corporate management practices and basing accountability on levels of student achievement (Ball et al. 2017). Lemov's bestselling 'Teach Like a Champion', the 'No Excuses teaching bible' (Horn 2016, 32) has been hugely influential in the UK, particularly at the ARK academy chain, with whom Lemov has worked closely. In the US, the work of Lemov and Bambrick-Santoyo forms much of the curriculum at Relay Graduate School of Education, which was set up by Uncommon Schools and two other leading charter networks, KIPP and Achievement First. Their work is particularly significant because, as we will demonstrate, it provides an extensive, sophisticated model for school leaders to attempt to control the performance of students, as well as teachers, through systematically targeting students' thoughts, feelings, and behaviours

Should schools become HRM systems that incorporate students alongside teachers in the manner we describe in this paper, the implications would be considerable. The concept of a student culture has the capacity to function as a central organising principle of the school, engendering a fundamentally corporatised system of relations between the school and the student. As we consider in the discussion, such a settlement has the potential to be a totalitarian one (Willmott 1993; Courtney and Gunter 2015); it could mean that schools would aim to systematically regulate the 'insides' of the child their thoughts and feelings - with the purpose of ensuring that they view their self-identity through the prism of whether or not they are the 'appropriate' kind of student in the eyes of the school (Alvesson and Willmott 2002). We now provide an overview of HRM and 
corporate culture, outlining their influence on schools, before taking up the example of Uncommon Schools as a fully corporatised model of schooling.

\section{HRM and corporate cultures}

HRM, an overarching term for an array of practices through which organisations select, train, and develop their employees, can be defined most simply as 'the management of work and people towards desired ends' (Boxall et al. 2007, 1). In Kaufman's (2007) account of the historical development of HRM, the roots of HRM are to be found in the 'scientific management' of organisations in the early twentieth century. HRM involved taking a 'scientific' approach to managing employees and calculating how to extract from the employee the greatest value for the organisation. Since the early 1980s, HRM has become the dominant approach to managing employees, replacing 'personnel management' and 'industrial relations'. According to Kaufman, the difference between HRM and what came before it is that HRM positions the employee as an important asset which must be strategically managed in order to secure a 'competitive advantage' (ibid. 36). HRM, therefore, should be undertaken in part by taking the humanness of the resource into account, so that the workplace meets the 'psychological and social needs and aspirations' of the employee (ibid. 35).

For Kaufman, the change in terminology between personnel management and HRM is emblematic of a different imagined system of relations between the organisation and the employee. While the personnel management/industrial relations model was based in part on the strategic management of the employee towards organisational ends, which included managing the wellbeing of the employee, it also acknowledged that the employees and the organisation do not always share the same interests, and at times mediation between the two is needed. The model is therefore pluralist, aware of and 
responsive to different perspectives within the organisation. HRM dropped this pluralist approach in favour of a system that envisages a unity of interest between the employees and the organisation:

The bedrock idea is that by treating employees as organisational assets rather than disposable commodities, structuring work to make it more interesting and selfcontrolled, and creating mutual-gains forms of compensation the employment model is transformed from an inflexible, high-conflict, and low productivity system [...] to a flexible, low-conflict and high-productivity unitarist HRM system. (ibid. 35)

Such 'high-commitment HRM' recognises that bureaucratic rules cannot control the workers' level of commitment. Employees might be outwardly conforming to what is expected of them, without really putting their heart and soul into the work. In order to secure the discretionary effort of the employee, working hard must become meaningful to the employee.

Accordingly, the HRM system attempts to systematically align the employees with the goals of the organisation through "managing the "insides" - the hopes, fears, and aspirations - of workers, rather than their behaviours directly' (Deetz 1995, 87). For instance, the organisation symbolically rewards employees as they contribute to the success of the organisation so that they feel like 'winners' (Peters and Waterman 1982). This form of control can be understood as 'identity regulation', which operates 'through the self-positioning of employees within managerially inspired discourses about work and organization with which they may become more or less identified and committed' (Alvesson and Willmott 2002, 620). HRM pairs such apparently 'soft' practices, which aim to ensure that work is meaningful for the employee with 'hard' practices, which direct, monitor, measure and evaluate the work of the employee. It is important not to 
draw false distinctions between the two. In both cases, the person is being managed as a resource, and it should be noted as we shift attention towards students that the 'soft' does not replace the 'hard', but works alongside it (Kärreman and Alvesson 2004).

Corporate culture is the systematisation of identity regulation (Willmott, 1993), as management builds various mechanisms that attempt to shape what it means to belong to the company into its everyday processes (Deal and Kennedy 1982; Kunda 1992). Although problematic from a 'purist' anthropological perspective (Willmott 1993, 521522), writers such as Ouchi (1981), Deal and Kennedy (1982), and Peters and Waterman (1982) long ago popularised the idea that culture can be imposed on an organisation from above by management in order to promote the commitment and effort of employees. Through a strong corporate culture, the employee is thought to gain a sense of meaning in an otherwise atomized world and, in turn, will work longer and harder. The mechanisms for creating a sense of belonging may include, but are not limited to, rituals such as songs, assemblies, socials; shared ways of talking (about work, the company, oneself); shared norms such as 'going the extra mile'; and heroic stories about the history of the company. As the corporation becomes a 'clan' (Ouchi 1981) or 'tribe' (Deal and Kennedy 1982) the leadership is able to manage what it means to be part of the group, centering the meaning of the company around shared values, such as 'a love of product', that lead to more committed, industrious employees (Willmott 1993, 522).

\section{HRM in schools}

Courtney and Gunter $(2015,400-401)$, describe the key elements of the transformation towards an HRM type system in schools led by a 'visionary' headteacher. First, whereas the local authority was primarily responsible for providing education to children in all schools throughout the local area, responsibility is now vested in the school itself, as a 
quasi-unitary entity. Each school is measured and compared on the student exam scores it 'delivers' (Ball et al. 2012); the logic, borrowed from the marketplace, is that holding schools to account, in a public way that is visible to parents, leads to improved performances in schools as they compete against each other (Courtney 2015b).

Second, the principal is positioned as a CEO-type figure 'causally responsible' for the success of the school (Courtney and Gunter 2015, 401), trusted to ensure high standards in the school because of their generalised management expertise (Gunter 2012). The principal is expected to identify specific areas where the school must improve, and take steps to improve the performance of staff, who are positioned, like human resources, 'as the objects that leaders and leadership impacted upon' (Gunter 2012, 2). Leaders effect improvement through being prescriptive about teachers' work, requiring teachers to follow management-imposed systems, while also closely monitoring their performance (Courtney and Gunter 2015).

Third, the principal should effect improvement using the HRM approach of combining the 'hard' accountability measures with management of the 'softer' aspects described above, such as attempting to shape the meaning that teachers attach to their work. This softer form of management functions 'through direction setting, charismatic command of loyalty and commitment, and through the right to manage others' attitudes, activity and performance' (Courtney and Gunter 2015, 401). From this perspective, leadership should be high-commitment or transformational, securing the discretionary effort of employees and aligning the identity of the employee with the organisation (Leithwood and Poplin 1992).

Fourth, the principal is expected to establish a 'vision' for the whole school, which sets out what the aims of the school are and what the 'culture' of the school is (Courtney and Gunter 2015). Following the popularisation of building corporate cultures, the idea 
that the principal should similarly shape the school culture in order to promote achievement has become commonplace (MacNeil et al. 2009). In Ofsted's latest school inspection handbook, school culture is placed at the top of the list of criteria for outstanding leadership and management:

Leaders and governors have created a culture that enables pupils and staff to excel. They are committed unwaveringly to setting high expectations for the conduct of pupils and staff. (Ofsted 2016, 41, emphasis added)

Like the CEO, the principal 'must build a shared sense of mission and a set of core beliefs, values, and norms' (Deal and Peterson 1990, 88), by embedding rituals, routines and symbols that celebrate achievement into the everyday life of the school (Deal and Kennedy 1982; Deal and Peterson 1990). Significantly, the student is positioned alongside the teacher within the culture; the culture aims to improve the values, attitudes and ultimately, the productivity of the student no less than the teacher (Sergiovanni 1987; Deal and Peterson 1990; Leithwood et al. 2004; Ofsted 2016). In the next section, through the example of Uncommon Schools, we show that this positioning of students within a managed, achievement-focused, corporatised school culture is potentially greatly significant in shaping the relationship between the school and the student.

\section{Uncommon Schools HRM system}

The Uncommon Schools model demonstrates that the positioning of the student as a human resource - whose behaviour, attitudes and values are managed through a student culture - can be a central organising principle for how the school functions. The work of Bambrick-Santoyo (2012), in setting out the overall management system of Uncommon Schools, and Lemov (2015), in describing in great detail how the student culture 
component of the management system operates in practice, provide a comprehensively articulated model of how student culture is at once a fully-integrated part of the HRM system and at the same time is enormously powerful in determining precisely how teachers treat students on a moment-to-moment basis. We first provide an overview of the management system as a whole, before focusing on the management of the student through the student culture.

The Uncommon Schools network is a strong proponent of the corporatised-HRM school type. First, the network embraces the idea of schools as unitary, results-producing institutions. The mission of the network is to 'close the achievement gap [between children of lower and higher income groups] and prepare low-income scholars to graduate from college' (Peiser 2015, xxxi). To this end, the watchword is 'effectiveness' and the sole criteria for judging schools and teachers is the results which the students achieve in standardised test scores (Bambrick-Santoyo 2012; Lemov 2015). A strictly utilitarian, efficiency-based definition of the purpose of teaching is adopted, '[t]he goal in teaching is to take the shortest path from A (lack of knowledge and understanding) to B (durable long-term knowledge and understanding)' (Lemov 2015, 147), while the entire school syllabus is backward planned, in meticulous detail, from the requirements of national assessments (Bambrick-Santoyo 2012).

Second, the network embraces business-inspired management systems as the key to achieving excellent results. In their description of how a principal should lead a school, Bambrick-Santoyo and Lemov (who undertook an MBA at Harvard Business School so that he could 'improve school accountability'), borrow heavily from the management guru Jim Collins. In his bestselling books, the 'legendary' 'Good to Great' (Lemov 2012, xxiii), and the 'seminal' 'Built to Last' (Lemov 2015, 439), Collins chronicles how a CEO should run a corporation. Lemov (2015 2-17) and Bambrick-Santoyo (2012, 1-6) borrow 
Collins' goal, in aiming to understand what makes an organisation 'great' rather than merely 'good', and they adopt his method for discovering the secrets to greatness: first, to discover through data which organisations have achieved outstanding results over a sustained period; then, through studying how the results were achieved, to produce a blueprint for excellence for anyone to follow.

Bambrick-Santoyo and Lemov's description of an excellent educational leader closely resembles Collins' description of an excellent CEO. In each case, the secret to success is to focus very tightly on the critical area for success, ruthlessly ignoring activities extraneous to achieving results:

Collins: 'Much of the answer to the question of 'good to great' lies in the discipline to do whatever it takes to become the best within carefully selected arenas and then to seek continual improvement from there. $(2001,128)$

Lemov: success, $[\ldots]$ is a result of two things above all. The first is a relentlessness about spending time on the most important things and as little else as humanly possible. The second, far harder, is bringing an engineer's obsession to finding the way to do these things as well as humanly possible'. (2012, xxiii)

It is hard to overemphasise the importance attributed to the leader taking an extremely close interest in those areas determined to be critical to success. Collins and BambrickSantoyo $(2012,173)$ share the analogy of how a leader supervising the important processes of an organisation should be like an elite distance athlete who plans every detail of their preparation, even 'rinsing their cottage cheese' to remove any extra fat (Collins 2001, 127). 
In Uncommon Schools this means that leader supervises the work of teachers in great detail, a process which 'ensures great teaching to guarantee great learning' (Bambrick-Santoyo 2012, 6). The particular metaphor invoked by Bambrick-Santoyo to describe the power of the principal over the quality of teaching and learning is the notion of seven 'levers' which enable the principal to 'make his or her school exceptional' (ibid. 5). As set out below, the levers allow the principal to control staff through holding them accountable against systems of procedures and measurement which encompass the whole scope of the teacher's professional life.

In the data-driven instruction lever, teachers must conduct assessments at least every eight weeks to ensure students are on track to succeed in the end of year national tests, with ongoing 'mini-assessments' undertaken in the interim; within 48 hours teachers produce 'assessment reports' for each student and for the whole class; the leader then meets with the teacher to agree an 'action plan', and to supervise the teacher as they rewrite lesson plans; the teacher is then observed to ensure that the action plan is being carried out (ibid. 21-53).

In the observation and feedback lever, the principal observes teachers every week. There is then a meeting in which the principal provides feedback designed to increase student performance in assessments; the teacher is required to immediately practice the feedback in front of the principal. The principal observes the next week to ensure that the action plan has been put into practice and to provide additional feedback, with the cycle continuing (ibid. 59-102).

In the instructional planning lever, the leader meets with teachers weekly, and ensures that the planning is tightly linked to the objective of achievement in the end of year test (ibid. 109-128). In the professional development lever, the leader determines exactly how the teachers need to develop, and holds teachers to account for integrating 
the new technique into their lessons through follow-up observations (ibid. 129-156). In the managing school leadership teams lever, 'iron sharpens iron' (ibid. 221-233) as the principal monitors and gives feedback to senior leaders on how they monitor and give feedback to teachers. Through the levers, the leader is positioned as the CEO-type leader endowed with the power to achieve excellent results through the managerial control of teachers, while the teacher's authority is arguably weakened as they are positioned as human resources to be monitored, directed and improved by the leader.

While the levers described above are 'hard' means of directly regulating, monitoring and intervening in the work of teachers, the staff culture lever, echoing the 'corporate culture' described above, concerns the 'softer' aspects of professional life, such as how teachers feel about their work, and how they relate to colleagues (as set out in a chapter written by Brett Peiser (2012) in 'Leverage Leadership'). The purpose of creating a strong staff culture is to provide staff with 'an internal motivation to work harder' (Peiser 2012, 208), which can be achieved since how people feel is 'surprisingly malleable'; (Achor 2012, quoted by Peiser 2012, 191); if the school leader creates the right culture, staff positively embrace the pressurised work environment: '[w]hen leaders create a vibrant and joyful culture, teachers are more willing to be held accountable, and more willing to do the hard work that makes a school work' (Peiser 2012, 190, emphasis originalf).

Despite covering the softer aspects of work, the staff culture lever is no less controlling of staff than other levers. Staff culture, like corporate culture, is best understood as paradoxical: it assumes the guise of a shared set of values, while at the same time acting as a set of expectations, enforced by the leadership, about how staff should behave. In maintaining the culture, the principal will react immediately if she hears that a staff member is 'frustrated with a requested task', 'seems disengaged during 
professional development' (ibid. 202), or fails to correct a 'student uniform violation' in the expected way (ibid. 215); in each case, the principal will take the matter up with the teacher and, where necessary, remind them of the school's expectations. A staff culture is a prescribed culture, in which there are right and wrong ways of being in school, and it is for the principal to regulate people's behaviour to ensure that they are conforming to expectations.

\section{The student culture lever}

As described in 'Leverage Leadership', Uncommon schools are ideal-type HRM organisations: quasi-unitary organisations 'producing' results, with the principal controlling, through exhaustive management processes, how staff work and how they feel about their work. As we describe below, this is only half the story of the HRM system. In addition to the staff-directed levers, there is a seventh 'super-lever', student culture, directed at improving the performance of the school through targeting the identities of students (Bambrick-Santoyo 2012, 163-186; Lemov 2015). It is termed a 'super-lever' because, alongside the data-driven instruction lever, it is considered to be the most effective way for the principal to improve student achievement (Bambrick-Santoyo 2012, 16). Working alongside the staff-focused levers, the student culture lever ensures that students are optimising their potential for learning: 'if the instructional levers help to make sure teachers are teaching as effectively as possible, student culture makes sure students build the habits of mind and heart that allow their learning to fly' (BambrickSantoyo 2012, 168). With particular reference to the classroom, but applicable to the school as a whole, student culture can be defined as the process of 'making your room a place where students work hard, model strong character, are polite and attentive, and strive to do their best' (Lemov 2015, 342). This definition captures the power over the 
student that the student culture lever affords to the leader. As we detail below, the leader uses the power to ensure that the student becomes the ideal student, who not only conforms to the school's rules but internalises the school's notion of precisely how a student should act at all times.

Like corporate culture systems, the student culture lever ensures that students live in accordance with the vision of the leader on two levels: it regulates behaviour alongside regulating identity. We first outline the regulation of behaviour, before describing the regulation of identity. The leader ensures that students act, think, and feel in accordance with the leader's vision by establishing 'meticulously built' (Bambrick-Santoyo 2012, 168) and fully comprehensive 'cultural systems' specifying precisely how students should be throughout the school day, from the moment students arrive at school, to assembly, break times, and classes (ibid. 168-175). In Lemov's $(2015,453)$ business language, teaching students to be 'disciplined' in this way is 'a front-end investment in teaching your students how to be students'. As examples, the students must follow the schoolapproved procedure for opening their lunch ('poke, pull, eat') (Bambrick-Santoyo 2012, 170), and when arriving at the morning meeting it is expected that 'students smile, heads up, and follow the line of tape on the floor to stand in the appropriate spot in the circle' (ibid. 172). Uncommon Schools advocates a 'sweat the details' policy based on 'the idea behind the broken windows theory of policing' of cracking down on all transgressions no matter how minor in order to 'create the perception of order' (Lemov 2010, 195-196). The name of the technique was dropped from the 2015 edition of 'Teach Like a Champion', perhaps because of the controversy around the policy in relation to the deaths of unarmed black men at the hands of the police (Bouie 2014). This is of particular significance since in comparison to publicly run schools a larger proportion of charter school students are African American (Berends 2015). Even though the term was dropped 
from the 2015 edition, the idea did not; the teacher is expected to manage the classroom so that all students are on task at all times: 'great teachers ensure that they have 100 percent of students with them for the teaching and learning; their expectation is 100 percent of students, 100 percent of the time, 100 percent of the way' (Lemov 2015, 387). In enforcing total conformity and commitment, the student culture lever shares with the staff-focused levers two corporate motifs: efficiency and accountability. The school day is interpreted as a finite amount of time available to teachers to ensure that students are working towards improving their test scores. Accordingly, Lemov advocates creating in-class routines to ensure that tasks are carried out as efficiently as possible. For instance, given the potential minutes saved over a school year it is 'all but a moral imperative' to have students practice tasks, such as handing out papers, as quickly as possible, with the inference that teachers ought to time these activities to avoid 'faux efficiency' (ibid. 12). The language employed is suffused with business terminology: creating efficient procedures is a 'strategic investment', while 'systematizing any activity lowers its transaction cost and increases the efficiency of its output' (ibid. 365). In terms of accountability, defined as 'students' feeling responsible for doing quality work to the best of their ability' (ibid. 325), Lemov advocates ensuring that as much of students' work as possible is made visible to the teacher and to peers. For instance, in 'show call', 'incredibly powerful as an accountability tool for writing' (ibid. 291), the teacher will project the work of a student, chosen at random, on the wall of the classroom.

With regard to identity regulation, student culture shares with staff culture the conviction that people are 'surprisingly malleable'. Student culture is perhaps best understood as the means through which the school works to determine the results of the following 'experiment' (Lemov 2015, 439): 
[Students] experiment with decisions about who they are and what their relationship will be to the people and institutions around them. Our goal as teachers is to do as much as we can to help those experiments turn out successfully, but also to remember the nature of the experiments. We want the result to be "Ah, I like it when I work hard and engage fully in learning."

These lines encapsulate the nature of the student culture lever, which, echoing corporate culture, systematically targets the student so that they come to understand themselves in ways deemed to be advantageous both to the student and to the school.

This mutually beneficial situation should not be understood as an equal or free partnership; rather, the system is built and led by the principal, and it contains a highly restrictive notion of who the student should become. The purpose of a corporatised student culture is to create an environment in which the students internalise the school's rules and expectations. In Lemov's terminology, this is to move from "behave" to "believe":

\footnotetext{
Although less visible than getting kids to behave, getting them to believe - to want to behave positively - is necessary to long-term success and to a healthy classroom culture [...] If influence is the process of instilling belief, maximizing it should be an intentional goal of every teacher's classroom culture. (ibid. 346, emphasis original)
}

Beyond influencing students so that they desire conforming to the school's behaviour policy, the purpose of the student culture lever is to align the student's identity with the school's vision of high academic attainment for all: 
In a thousand different ways, from morning meeting to math to reading to lunch, Rochester Prep students continually hear this message: nothing is as important or as engaging - as learning. Learning is the means to develop a sharp mind and a strong character, and it opens the door to a brighter future. (Bambrick-Santoyo 2012, 164)

Within a corporatised student culture, there are innumerous ways of channeling identity towards performance (Alvesson and Willmott 2002). While Lemov's book is presented as an atheoretical 'taxonomy of effective teaching practices' (Atkins 2015, xxii), the book is in fact steeped in Uncommon Schools ideas about education described above, in which the purpose is to maximise the efficiency and commitment of the students. Lemov (2015, 425-426) asserts that the teacher should consider how each interaction with students may be used as a means of developing the appropriate student identity; the book, particularly the section covering classroom culture, provides the teacher with sufficient techniques so that every moment in the classroom is structured so that the teacher is able to shape the identity of the students. We now describe some of Lemov's techniques through which identity can be leveraged to secure higher levels of commitment and results.

At Uncommon Schools, students are not students, they are 'scholars'. The label serves as an immediate form of identity regulation, since to be a scholar is of course to be a particular type of student, one who is studious and deeply engaged. Referring to students as scholars is a flexible way of improving behavior and attitudes, applicable to almost any situation in school from requiring students to sit up straight, enter a classroom appropriately, or use complete sentences (ibid.). The techniques described below - 'peer support' 'strategic positive reinforcement', 'joy factor', and 'self-management' - are all ways of providing the scholar identity with substance, working towards a situation where being a 'scholar' can be a coherent way of being throughout the school. They are only a 
small fraction of the 'thousand different ways' of the school's 'cultural system'. They have been chosen because they each regulate the identity of the student in a different way, ensuring that the student adopts the school-approved attitude towards themselves, their peers, their work, and the school environment. While the examples are not an exhaustive list, they do indicate the level of detail involved in the student culture lever's systematic attempts to regulate the identity of the student, and the extent to which the lever is ingrained into the everyday life of the school.

\section{Peer support}

As a way of building on the scholar identity, students are encouraged to act as teammates who 'actively support one another as they struggle through the learning process' (ibid. 66). Lemov approvingly cites a school which insists on the students undertaking particular supportive actions at appropriate times: '[w]hen someone is struggling to answer a question, peers (or teachers) "send love," making a subtle hand gesture that means, "I'm supporting you"' (ibid. 67). Additionally, the teacher should praise questions so that 'the kids start to view their class as a team - working together toward the common goal of mastery' (ibid. 65). 'Props' are a 'form of public praise undertaken by students for peers who demonstrate excellence or exemplify virtues', where the students create a quick sound (e.g. 'oh, yeah!') with movement (ibid. 372). Like any other routine, students practice props until they are proficient, and participation is enforced (ibid. 372). Equally, props are deemed to be an efficient use of class time: '[i]f you can consistently enable classmates to deliver resounding praise to one another in two seconds flat, you can build a culture that valorizes achievement and effort without sacrificing order or time on task' (ibid. 372). 


\title{
Strategic positive reinforcement
}

The scholar identity is further reinforced through the practice of 'strategic positive reinforcement'. This functions through demanding more from students in such a way that they want to be better. It is a means of narrating a story 'about the future' (ibid. 434) of the scholar who is forging the best possible version of themselves:

\begin{abstract}
When you ask students to do something differently or better, you are helping them become the people they wish to be or to achieve enough to have their choice of dreams. You can use the moments where you ask for better to remind them of this. When you ask your students to revise their thesis paragraphs, tell them you want them to write as though "they're in college already" or "that with one more draft, they'll be on their way to college." (ibid. 432)
\end{abstract}

Strategic positive reinforcement is recommended as a technique that teachers practice at all times across the school, whether they are disciplining students, chairing a class discussion, or giving praise (ibid.). It is used as a means of managing the rigorous enforcement of high standards in school so that students identify with the demanding nature of school, and develop the capacity to drive themselves to do better. For instance, providing positive reinforcement in the 'no opt out' technique, where the student is required to give a correct answer when called upon, even if they need additional support, enables the teacher to 'leverage traits like grit and persistence so they happen more often' (ibid. 99). In the 'do it again' technique, the teacher asks the class to perform a task again, even if the standard achieved the first time was acceptable. When combined with the positive reinforcement that the class can be even better, the technique can 'drive your classroom culture by replacing acceptable with excellent, first in small things and then in all things' (ibid. 374). In the 'stretch it' technique, the teacher asks the student to improve 
on an answer; framing this demand positively, such as by telling students that they should say more because the original answer was a good one. This technique encourages a “" growth mindset." You want students who don't think, "Oh no, this is going to be a hard problem", but instead think, "Oh, yeah, this is going to be a hard problem"” (ibid. 116). Ideally, by systematically putting a positive spin on hard work across the school, a culture is created whereby it becomes part of who students are.

\section{Joy factor}

In the Uncommon Schools approach students are expected to be working, often on basic tasks, from the moment the lesson begins ('strong start' technique) until the very end. Student culture supplements this strong behavioural expectation with moments of joy and surprise 'harnessed judiciously' by the teacher to ensure that the students remain motivated (ibid. 445). Joy is treated as 'tool' (ibid. 444) considered particularly useful in transforming the experience of a curriculum reverse planned from national tests: '[p]eople work harder when they enjoy working on something - not perhaps in every minute of the day, but when their work is punctuated regularly by moments of exultation and joy' (ibid. 442). The distinctive element of 'joy factor', as opposed to the idea of simply making a lesson fun, is the way that it is closely and deliberately tied to the efficient learning of the students. The fun is highly managed with the specific purpose of efficiently increasing the motivation of the student:

Good joy factor in the classroom has to be "the servant" - that is, its purpose is to support the day's objective. It should also be something you can quickly turn on and off $[\ldots]$ A champion teacher recognizes that his job is not only to share joy but also to teach students to manage the joy. (ibid. 442-443) 
In terms of the scholar identity, bringing joy into an industrious classroom, like being simultaneously 'warm-strict', teaches students that there is no loss in being a scholar; '[i]t reminds students that many of the either-or choices in their lives are false constructs: "I can be hip and successful; I can have fun and work hard; I can be happy and say no to self-indulgence."' (Lemov 2015, 439, emphasis original)

\section{Self-management}

When students are able to achieve a particular routine without direct instruction from the teacher, the teacher should transfer 'ownership' of the routine to them. In practice, this means that the teacher no longer instructs the class to do something when the class know to do it without needing to be told. However, significantly the teacher still observes and intervenes if students depart from doing what is expected of them. According to Lemov, paraphrasing a teacher, this practice gives students the 'freedom to self-manage' (ibid. 370). This 'self-management' is useful from the perspective of student culture in two ways. First, it leads to more efficiency, since it eliminates the time for students to be asked to do something. Second, it motivates students by altering how they feel about the rules, as students gain 'a greater sense of accomplishment, independence, and ownership' (ibid. 368). Students learn that autonomy is not gained through resisting the school's rules, instead it 'is earned via mastery and follow-through' (ibid. 370); there is freedom in being a scholar. Student culture here manages the meaning of 'freedom' so that, ironically, students feel free when they are most meticulously following the school's rules. This form of management, of tightly controlling the individual while in the same breath promoting a sense of freedom, is perhaps the defining feature of corporate cultures (Willmott 1993).

The above examples demonstrate that within the student culture lever, teachers (under the supervision of the principal) have at their disposal the techniques to turn almost 
any given situation into an opportunity for shaping the identity of the student, so that the student adopts the school-approved attitude towards themselves, their peers, their work, and the school environment. The techniques enable the teacher to rationalise and instrumentalise any given moment, so that a pro-achievement, pro-authority orientation is insisted upon, as the possibilities for experience and self-understanding are narrowed. They reveal the extent to which, in the Uncommon Schools model, the insides of the students are brought into the orbit of the management system and 'leveraged' by the school leadership in order to achieve the organisation's goals.

\section{Conclusion}

This paper demonstrates that, within an influential part of the 'Global Education Reform Movement', the management system extends beyond staff to incorporate the student. The student is positioned as a human resource whose behaviour, thoughts, and feelings are systematically monitored, regulated, and improved in order to maximise achievement. Given the nature of the experience of teachers under managerial regimes in the contemporary school, the new corporatised position of the student is potentially highly significant. The most pressing questions concern what being incorporated within the management system could mean for students. While the significance of this system can only be evaluated through empirical research in schools, the purpose of this article is to articulate the potential effects of the system. In considering the fullest possible extent of the effects of corporatised school cultures, Willmott's classic polemic on corporate cultures provides a useful starting point. Willmott $(1993,517)$ argued that, by systematically 'promoting employee commitment to a monolithic structure of feeling and thought', corporate culture functions as a type of totalitarian system 
In certain respects the potential of a totalitarian system within corporatised schools is perhaps even greater than in the business world. There is an important difference between the adult and child in terms of status, which means that it may be much easier, and more legitimate, to impose controls on the child. As we have argued in this article, the potential extent of the control is considerable. The school expects 100 per cent compliance, and reacts to every behavioural transgression. Furthermore, behavioural codes are fine-grained, with expectations for exactly how students should perform various school routines and how should hold themselves inside and outside of class. Lemov $(2015,61)$ advocates synonyms and gestures so that it is possible to continuously correct behaviour as efficiently as possible (for instance SLANT means 'Sit up, Listen, Ask and answer questions, Nod your head, Track the speaker'). Although there are of course significant behavioural controls in the corporate world, the extent of the behavioural controls in the Uncommon Schools approach extends as far as the imagination of staff (e.g., 'poke, pull, eat').

In addition to greater controls on behaviour, there is also greater scope for the regulation of identity in school culture than in corporate culture. In corporate culture, while the organisation may well aim to control how employees feel, in practice the nature of working life means that there is often a distance between the employee and the leadership who enforce the cultural system. For instance, in meetings and presentations with senior leadership, an employee espouses the officially-sanctioned identity, but in lower level meetings employees are able to be far more cynical and removed from the culture (Kunda 1992). By contrast, in schools, leaders and staff are able to monitor and enforce the prescribed ways of being in school to a much greater extent. The system for regulating student identity - consisting of the various rituals, procedures, and interactions - operates throughout the school day. It is extremely detailed, starting from the moment 
the students arrive on buses and encompassing informal time-spaces such as lunchtime (Bambrick-Santoyo 2012, 163-186). In each lesson the teacher is expected to be continuously shaping how students feel about themselves and their work, with students expected to respond in the required way. When students are in school, they are expected to feel that they are in a special place; when working, they are expected to be pleased to be progressing towards college; when another student does well, they are expected to be joyful (Lemov 2015). Would it be entirely unreasonable to be concerned that we are close to a type of 'monolithic structure' being rigorously imposed on students?

We should of course be somewhat sceptical of the notion that students' thoughts and feelings could ever be under the total control of school leadership. In terms of the effects of high-commitment HRM identity regulation practices, few would defend the view that the employee is a 'stencil' shaped by the organisation at will (Alvesson 2010). Since the individual possesses a degree of reflexivity, with the capacity to consider themselves in relation to organisational discourses and practices, identity regulation by the organisation 'is a precarious and often contested process' (Alvesson and Willmott 2002, 621). This is not to say the student culture would not have any affect, since the student would have to navigate the culture. The culture would, at the very least, serve as an additional demand on students, to demonstrate that they are the appropriate kind of person. In performing the appropriate identity, there are likely to be winners and losers, since some students would feel more alienated from the appropriate school identity than others, while some students may be more adept than others at performing the appropriate identity. In a sense the stakes of existing in such a system are higher for students than for teachers. Not only is school a formative time for the construction of children's identities, but students do not share the degree of freedom that teachers have, of simply leaving if they are unable to thrive in an HRM system (Courtney and Gunter 2015). 


\section{References}

Achor, S. 2012. “Positive intelligence.” Harvard Business Review 90 (1): 100-102.

Alvesson, M. 2010. "Self-Doubters, Strugglers, Storytellers, Surfers and Others: Images of SelfIdentities in Organization Studies." Human Relations 63 (2): 193-217. doi: $10.1177 / 0018726709350372$

Alvesson, M., and H. Willmott. 2002. "Identity Regulation as Organizational Control: Producing the Appropriate Individual." Journal of Management Studies 39 (5): 619-644. doi: 10.1111/1467-6486.00305.

Atkins, N. 2015. "Foreword" to Teach Like a Champion 2.0, by D. Lemov, xxi-xxiii. San Francisco, CA: Jossey-Bass.

Ball, S.J. 2003. "The Teacher's Soul and the Terrors of Performativity." Journal of Education Policy 18 (2): 215-228. doi: 10.1080/0268093022000043065.

Ball, S.J., M. Maguire, A. Braun, J. Perryman, and K. Hoskins. 2012. “Assessment Technologies in Schools: 'Deliverology' and the 'Play of Dominations"' Research Papers in Education 27 (5): 513-533. doi 10.1080/02671522.2010.550012.

Ball, S. J., Junemann, C., and Santori, D. 2017. Edu. Net: Globalisation and Education Policy Mobility. London: Routledge. 
Bambrick-Santoyo, P. 2012. Leverage Leadership. San Francisco, CA: Jossey-Bass.

Berends, M. 2015. "Sociology and school choice: What we know after two decades of charter schools." Annual Review of Sociology 41: 159-180.

Bouie, J. 2014. “Broken Windows Policing Kills People.” Slate, August 5. http://www.slate.com/articles/news_and_politics/politics/2014/08/broken_windows_pol icing_deaths_racism_in_chokeholds_arrests_and_convictions.html

Boxall, P., J. Purcell, and P. Wright. 2007. "Human Resource Management: Scope, Analysis, and Significance." In The Oxford Handbook of Human Resource Management, edited by P. Boxall, J. Purcell, and P. Wright, 1-18. Oxford: Oxford University Press.

Collins, J. 2001. Good to Great. London: Random House.

Courtney, S.J. 2015a. "Corporatised Leadership in English Schools.” Journal of Educational Administration and History 47 (3): 214-231. doi: 10.1080/00220620.2015.1038694.

Courtney, S.J. 2015b. "Mapping School Types in England.” Oxford Review of Education 41 (6): 799-818. doi: 10.1080/03054985.2015.1121141.

Courtney, S. J., and H.M. Gunter. 2015. "Get off my Bus! School Leaders, Vision Work and the Elimination of Teachers.” International Journal of Leadership in Education 18 (4): 395417. doi: 10.1080/13603124.2014.992476. 
Deal, T., and A. Kennedy. 1982. Corporate Cultures. Reading, MA: Addison-Wesley.

Deal, T., and K. Peterson. 1990. The principal's role in shaping school culture. Washington, DC: U.S. Department of Education.

Deetz, S. 1995. Transforming Communication, Transforming Business. Cresskill, NJ: Hampton Press.

Grace, G. 1995. School Leadership: Beyond Educational Management. London: Falmer Press.

Gunter, H. 2012. Leadership and the Reform of Education. Bristol: Policy Press.

Hatcher, R. 1994. "Market Relationships and the Management of Teachers." British Journal of Sociology of Education 15 (1): 41-61. doi: 10.1080/0142569940150103.

Horn, J. 2016. Work Hard, Be Hard. Lanham, MD: Rowman \& Littlefield.

Kärreman, D., and M. Alvesson. 2004. "Cages in tandem: Management Control, Social Identity, and Identification in a Knowledge-Intensive Firm.” Organization 11 (1): 149-175. doi: $10.1177 / 1350508404039662$.

Kaufman, B. E. 2007. "The Development of HRM in Historical and International Perspective." In The Oxford Handbook of Human Resource Management, edited by P. Boxall, J. Purcell, and P. Wright, 19-47. Oxford: Oxford University Press. 
Kunda, G. 1992. Engineering Culture. Philadelphia, PA: Temple University Press.

Leithwood, K. and M. Polin. 1992. "The Move toward Transformational Leadership." Educational Leadership 49 (5): 8-12.

Leithwood, K., K. Louis, S. Anderson, and K. Wahlstrom. 2004. How Leadership Influences Student Learning. New York: The Wallace Foundation.

Lemov, D. 2010. Teach Like a Champion. San Francisco, CA: Jossey-Bass.

Lemov, D. 2012. "Foreword” In Leverage Leadership, by P. Bambrick-Santoyo, xxi-xxiv. San Francisco, CA: Jossey-Bass.

Lemov, D. 2015. Teach Like a Champion 2.0. San Francisco, CA: Jossey-Bass.

MacNeil, A., D. Prater, and S. Busch. 2009. "The Effects of School Culture and Climate on Student Achievement." International Journal of Leadership in Education 12 (1): 73-84. doi: $10.1080 / 13603120701576241$.

Ofsted. 2016. School Inspection Handbook. London: Ofsted.

Ouchi, W.G. 1981. Theory Z. New York: Avon Books.

Peiser, B. 2012. “Staff Culture” In Leverage Leadership, by P. Bambrick-Santoyo, 189-219. San Francisco, CA: Jossey-Bass. 
Peiser, B. 2015. “About Uncommon Schools” In Teach Like a Champion 2.0, by D. Lemov, xxxixxxii. San Francisco, CA: Jossey-Bass.

Peters, T. J., and R.H. Waterman. 1982. In Search of Excellence. New York: Harper Collins.

Sergiovanni, T. J. 1987. "The Theoretical Basis for Cultural Leadership." In Leadership: Examining the Elusive, edited by L. T. Sheive and M. B.Schoenheit, 116-129. Alexandria, VA: Association for Supervision and Curriculum Development.

Vaughan, R. 2014. “'I Want to Honour All the Things That Teachers Are Doing'." Times Educational Supplement, November 28.

https://www.tes.com/news/tes-archive/tes-publication/i-want-honour-all-thingsteachers-are-doing

Wilkins, A. 2015. "Professionalizing School Governance: The Disciplinary Effects of School Autonomy and Inspection on the Changing Role of School Governors." Journal of Education Policy 30 (2):182-200. doi: 10.1080/02680939.2014.941414.

Willmott, H. 1993. "Strength is Ignorance; Slavery is Freedom: Managing Culture in Modern Organizations.” Journal of Management Studies 30 (4): 515-552. doi: 10.1111/j.14676486.1993.tb00315.x. 